\title{
CANAL WATER DELIVERY SYSTEM AUTOMATION. A CASE STUDY
}

\author{
M. RIJO \\ Department of Agricultural Engineering, University of Évora, Évora, Portugal \\ V. PAULO \\ Hidroprojecto Engenharia \& Gestão S.A., Lisbon, Portugal
}

\begin{abstract}
Upstream control in canals is efficient when associated with rigid water delivery methods. In practice, most of these systems work with flexible water delivery schedules and water operational losses become significant. Real-time technologies allow the water manager to continuously compare the actual management of the delivery system with its optimal management, and to take appropriate corrective steps as required. These innovations allow the manager to react rapidly and effectively to changing conditions. For these reasons, in Portugal, modernisation of upstream controlled canals uses remote monitoring and central control technologies. This paper presents the case study of the Mira Irrigation Project modernisation program.

Keywords: automation, irrigation canal modernisation, remote control, remote monitoring, upstream control, water saving.
\end{abstract}

\section{Introduction}

In many countries or regions, water is becoming the limiting factor for development. The marked competition between municipalities, industry and agriculture is pushing toward more efficient use of this limited natural resource.

Agriculture, the largest water consumer, has adopted modernisation programs based on new technologies to provide more reliable and flexible water delivery to farmers. An improved irrigation service will lead to high on-farm irrigation efficiency, less spillage and water losses within conveyance and distribution systems. These two factors will definitely decrease the water volumes required at the source.

The intervenients involved in water distribution must up-grade their service to

Water and the Environment: Innovative Issues in Irrigation and Drainage. Edited by Luis S. Pereira and John W. Gowing. Published in 1998 by E \& FN Spon. ISBN 0419237100 